August 2009

\title{
Failures to Prevent Genocide in Rwanda (1994), Srebrenica (1995), and Darfur (since 2003)
}

Fred Grünfeld

Wessel Vermeulen

Follow this and additional works at: https://digitalcommons.usf.edu/gsp

\section{Recommended Citation}

Grünfeld, Fred and Vermeulen, Wessel (2009) "Failures to Prevent Genocide in Rwanda (1994), Srebrenica (1995), and Darfur (since 2003)," Genocide Studies and Prevention: An International Journal: Vol. 4: Iss. 2: Article 13.

Available at: https://digitalcommons.usf.edu/gsp/vol4/iss2/13

This Articles is brought to you for free and open access by the Open Access Journals at Digital Commons @ University of South Florida. It has been accepted for inclusion in Genocide Studies and Prevention: An International Journal by an authorized editor of Digital Commons @ University of South Florida. For more information, please contact digitalcommons@usf.edu. 


\title{
Failures to Prevent Genocide in Rwanda (1994), Srebrenica (1995), and Darfur (since 2003)
}

\author{
Fred Grünfeld \\ Faculty of Law, Maastricht University; Maastricht \\ Centre for Human Rights; University College Maastricht; \\ Centre for Conflict Studies, Utrecht University
}

\section{Wessel Vermeulen \\ Doctoral student, Faculty of Law, Economics and Finance, University of Luxembourg}

This article presents the results of a comparative study of genocide prevention showing similarities that form a disappointing pattern of failure on the part of third parties to prevent genocide in three different situations: Rwanda, Srebrenica, and Darfur. Early, clear, and reliable warnings combined with a policy recommendation have not led to preventative action because they were not discussed by the responsible decision makers (Rwanda, Srebrenica) and/or because conflicting international concerns hindered firm action (Darfur). Instruments of prevention were available, in the form of UN peacekeeping troops who could have been empowered for successful prevention in combination with existing reinforcements (e.g., evacuation troops or NATO air support); however, this option was not on the decision makers' agenda. The main explanation for the decisions made by these third parties is their inability to perceive a change from a peace-settlement situation to an emerging genocide and their consequent inability to react to such a change adequately. Rwanda and Srebrenica may be explained in this way, but not Darfur. Here the situation is different and more complicated, as this study shows by reference to the continuing international attention to the situation, on the one hand, and the continuing inability of third parties to change the situation on the ground, on the other. Sudan's political position in the world, as well as the negotiating power the Sudanese government draws from domestic circumstances, has deterred decision makers from initiating measures against Sudan's national sovereignty.

Keywords: genocide prevention, early warning, Rwanda, Srebrenica, Darfur, UN decision making, bystanders

\section{Introduction}

In just 100 days, starting in the spring of 1994, an estimated 800,000 persons were killed in the Rwandan Genocide. ${ }^{1}$ The early warnings issued before the killings started were clear, and they were put forward to the responsible decision makers at the United Nations. The information came from the most authoritative and reliable sources available: the UN peacekeeper commanders in the field. This information was completely reliable, and the commanders sent their early warnings in combination with a request for instructions and proposals on how to act in the circumstances.

Fred Grünfeld, "Failures to Prevent Genocide in Rwanda (1994), Srebrenica (1995), and Darfur (since 2003)." Genocide Studies and Prevention 4, 2 (August 2009): 221-237. (C) 2009 Genocide Studies and Prevention. doi: 10.3138/gsp.4.2.221 
For instance, the request from peacekeepers in Rwanda to track arms caches-the so-called genocide fax-was sent on 11 January 1994, three months before the genocide began. The alarming information in the fax was not disputed by the UN secretariat, but the peacekeepers were refused authorization for action because the seizure of weapons was seen as going beyond their mandate. As we will describe below, hardly any decision making to prevent-or, later, to stop-the genocide took place in the Security Council. Tragically, the failures of Rwanda are being repeated today. The task of tracking arms caches, which was included in the mandate for the peacekeepers in Darfur, was deleted in Security Council Resolution 1769 on 31 July 2007. The main question addressed in this article is, What are the lessons to be drawn from the genocides in Rwanda, Srebrenica, and Darfur? Our discussion of Rwanda is based on the study The Failure to Prevent Genocide in Rwanda: The Role of Bystanders, published in $2007 ;^{2}$ the discussion of Srebrenica is based on a study published in 2008, "The Role of Bystanders in Rwanda and Srebrenica: Lessons Learned." ${ }^{3}$ The discussion of Darfur is based on ongoing research into early warning and early action between 2003 and 2008.

\section{Rwanda}

Long before the plane crash that triggered the ensuing events, the situation in Rwanda could have been described as a "possible genocide." 4 In the first week of the atrocitiesafter the plane crash-the killings were mostly of political adversaries (i.e., moderate political leaders), and can therefore be described as a politicide. In the second week, however, the killing of all persons from the Tutsi ethnic group began, with more than 100,000 killings committed in a week's time. A month into the genocide, about half a million people had been killed. After the second month, invading forces of the Rwandan Patriotic Front under Paul Kagame captured the last strongholds of the prior government, and the genocide came to an end. ${ }^{5}$

\section{Srebrenica}

In one week in mid-July 1995, 8,000 Muslim men and boys were killed in and near Srebrenica, the UN-protected "safe haven" in Bosnia-Herzegovina. As in Rwanda, UN peacekeepers failed to provide protection after the Bosnian Serbs conquered the area, which had earlier been designated as a safe area by the United Nations. We describe below a number of warnings in the months preceding the atrocities that made the genocidal intentions of the Bosnian Serbs clear. The International Court of Justice established these intentions more than ten years later when it condemned another third party, Serbia-Montenegro, for violating the obligation to prevent genocide in Srebrenica. In its judgment of 26 February 2007, the court held that "a state does not incur responsibility simply because the desired result is not achieved; responsibility is however incurred if the State manifestly failed to take all measures to prevent genocide which were within its power, and which might have contributed to preventing the genocide." More information on the Bosnian Serb policy is expected to emerge from the trial of Radovan Karadzić, arrested in 2008, before the International Tribunal for the Former Yugoslavia.

\section{Darfur}

In a period of five years-between 2003 and 2008-an estimated 300,000 Sudanese people of African origin, mostly male, have been killed in the Darfur region of Sudan. The killings began in February 2003; by the end of that year 10,000 had been killed, 
and the number of killings increased to 100,000 in 2004 and to 200,000 again from 100,000 . Since 2005 , the numbers have increased to about $300,000 .^{7}$ The perpetrators are members of the Sudanese army and armed groups supported by the authorities, such as the Janjaweed militia. Some scholars ${ }^{8}$ and policy makers ${ }^{9}$ have labeled this a genocide, while others categorize the same atrocities as crimes against humanity. ${ }^{10}$ No international jurisprudence has been issued in this case to date, and this article does not intend to contribute to the debate on whether or not genocide has occurred.

The first military revolt by the African Darfuri people-mainly the non-Arab Fur, Zaghawa, and Massaleit-in February 2003 was met directly with reprisals that had the characteristics of a beginning genocide. Events and developments in Darfur since 2003 have been reported from the start by many NGOs, states, and international organizations. No clear signals with respect to the intentions of these ethnic killings and the emergence of warfare from before 2003 are available. Because the magnitude of the killings was much more limited, and the events spread over a longer period, than in Rwanda, Darfur has been referred to as "Rwanda in slow motion." 11 The slow unfolding of events, the availability of information at an early stage, and remorse for the failures to act in Rwanda and Srebrenica made Darfur an outstanding case for political mobilization in the Western world to urge governments to act and stop the ongoing atrocities. The result, however, has been no better than in the other two cases.

This state of affairs raises a number of compelling questions: Why did international bystanders fail to act to prevent or to stop the genocides in Rwanda, Srebrenica, and Darfur? What are the similarities and differences among these cases? In what way would the international bystander have been able to act with the available instruments? Why were the warnings not translated into action, or, more precisely, what are the reasons for inaction or the ineffectiveness of the action that was undertaken? Who was involved in the international decision-making process, and why was that process continually hampered?

Before answering these questions, we will briefly describe, for each of the three cases, (1) the availability of information that could have been seen as early warning signs requiring action; (2) the availability of military and non-military instruments to prevent or stop these atrocities, here called genocide; and (3) the decision-making process that took place by governments and within the United Nations.

\section{Rwanda}

\section{Warning}

The warnings of the emerging genocide were already sounded a year before the killings began by many NGOs, ${ }^{12}$ by the UN special rapporteur on extra-judicial executions, ${ }^{13}$ and by diplomats. ${ }^{14}$ Actors in the international decision-making arena, however, viewed the situation in Rwanda as a resolved conflict, with a peace process beginning whereby a mutually agreed peace plan (the Arusha Accords) needed to be implemented - a job that could be done with a small, lightly armed peacekeeping force. This vision did not change when the UN peacekeepers stationed in Rwanda (the UN Assistance Mission for Rwanda, or UNAMIR) sent alarming reports to New York asking for a stronger mandate to seize weapons and for a bolstering of their forces to act against the extremists, ${ }^{15}$ including the "genocide fax" that unveiled the intention to kill Belgian peacekeepers and the Tutsi population. In the months preceding the genocide, all these warnings were received but did not change the decisions of the UN Secretariat, which continued to think in terms of peace and 
security and of the post-conflict transformation process of installing a new multi-ethnic government. ${ }^{16}$ In their bureaucratic vision, the UN had to maintain a traditional neutral peacekeeping role and not take sides against the perpetrators of the impending genocide through forceful action, as was requested by, for example, UNAMIR commander Lt.-Gen. Roméo Dallaire and the Belgian government. So the most reliable warnings, coupled with a policy recommendation on how to act, were forwarded and received in New York; but this information, including reports on the deteriorating situation, was not forwarded to the members of the Security Council, who were thus precluded from taking any action at all.

\section{Instruments}

The available instruments were rather weak, because, for reasons of political feasibility, the manpower and the mandate requested by the UN Secretariat from the Security Council were less than the situation required. No further options were put forward to the Security Council, despite requests from UN military experts and both parties to the Arusha Accords for a stronger mandate and more troops to implement the accords. Even with the available instruments, the peacekeepers were prohibited from taking action against the inciters of hatred and the planners of the genocide within the ranks of the extremists. After the genocide began and ten Belgian peacekeepers were deliberately killed, most of the remaining peacekeepers were ordered to leave the country when the Security Council approved their withdrawal in Resolution 912 (see Figure 1).

Perhaps the available instruments were too weak to enable action during the genocide or to stop the genocide. In order to evaluate this question properly, however, we must take two important considerations into account. First, the peacekeepers had been instructed in the six preceding months to act in a preventive way; they received no permission for forceful action from UN headquarters when the situation changed from "peace promotion" (i.e., facilitating the implementation of the peace accords) to the threat of an emerging genocide. The UN's main threat to the extremist rulers in Rwanda was that the peacekeepers would be withdrawn if stability were not achieved; in fact, however, this was the outcome the génocidaires were longing for. Second, at the beginning of the genocide a huge fighting force arrived in Rwanda to evacuate foreign nationals. ${ }^{17}$ The possibility of combining this strong military force with the weaker UN peacekeeping force was never tabled in any Western capital or at UN headquarters-a clear signal to the génocidaires that no one from outside Rwanda would obstruct the unfolding genocide.

\section{Decision Making}

The members of the Security Council were not informed by the UN Secretariat about the alarming situation in Rwanda because the highest-ranking civil servants at the UN, who had no political legitimacy, feared a collapse of their peacekeeping department after the failures in Somalia. ${ }^{18}$ During the genocide the Security Council decided, in Resolution 912, to withdraw the UNAMIR forces. A decision to start again with another peacekeeping force (Resolution 918) could not be implemented during the genocide; only after the RPF victory did France initiate an enforcement force based on Chapter 7 of the UN Charter (Security Council Resolution 929) to protect the Hutu refugees in the neighboring country (see Figure 1). No attempt to prevent or to stop the genocide was made by the bystanders, who in this case, perhaps more clearly than in any other case of genocide, became collaborators 


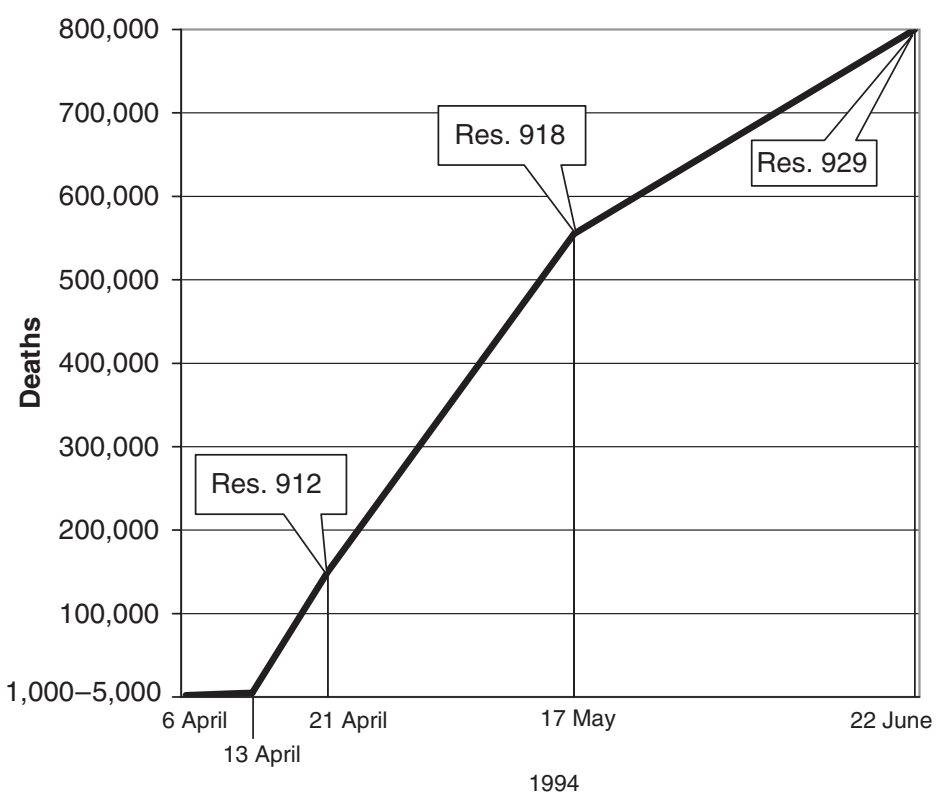

Figure 1. Deaths in Rwanda

of the perpetrators. All elements of genocide were very obvious; all were observed; but these observations were not acted upon. The "never again" spoken by so many after the Holocaust now rings alarmingly hollow: in 1994, 800,000 persons were killed within 100 days, with the most primitive instruments, while the most powerful states and international organizations, which had access to the most sophisticated instruments, knowingly allowed this to happen.

\section{Srebrenica}

\section{Warning}

Since January 1994, a detachment of peacekeepers from the Netherlands (Dutchbat) from the UN Protection Force (UNPROFOR) peacekeeping mission, had been charged with protecting the so-called safe area of Srebrenica. The official Dutch report on the events in Srebrenica ${ }^{19}$ argues that the enclave was taken by surprise and that because of the fall of the enclave, the genocide that took place could not have been prevented. According to this version of the events, no third party can be blamed for having failed to undertake preventive action. The situation is less comfortable than the report's authors suggest, however, for several reasons:

(1) At least two months before the attack occurred, members of the UN Security Council and the UN Secretariat were informed about the impending attack. ${ }^{20}$ They did not share this information with the Dutch government or military officials. $^{21}$ The possibility of preventive military enforcement was excluded by the UN and the major powers. No debate was held in the Security Council on maintaining the safe area in Srebrenica.

(2) The genocidal intent of Bosnian Serbs toward Bosnian Muslims was known to third parties. ${ }^{22}$ With this knowledge, the subsequent failure to act to prevent the genocide makes the third party a collaborator with the perpetrators; that 


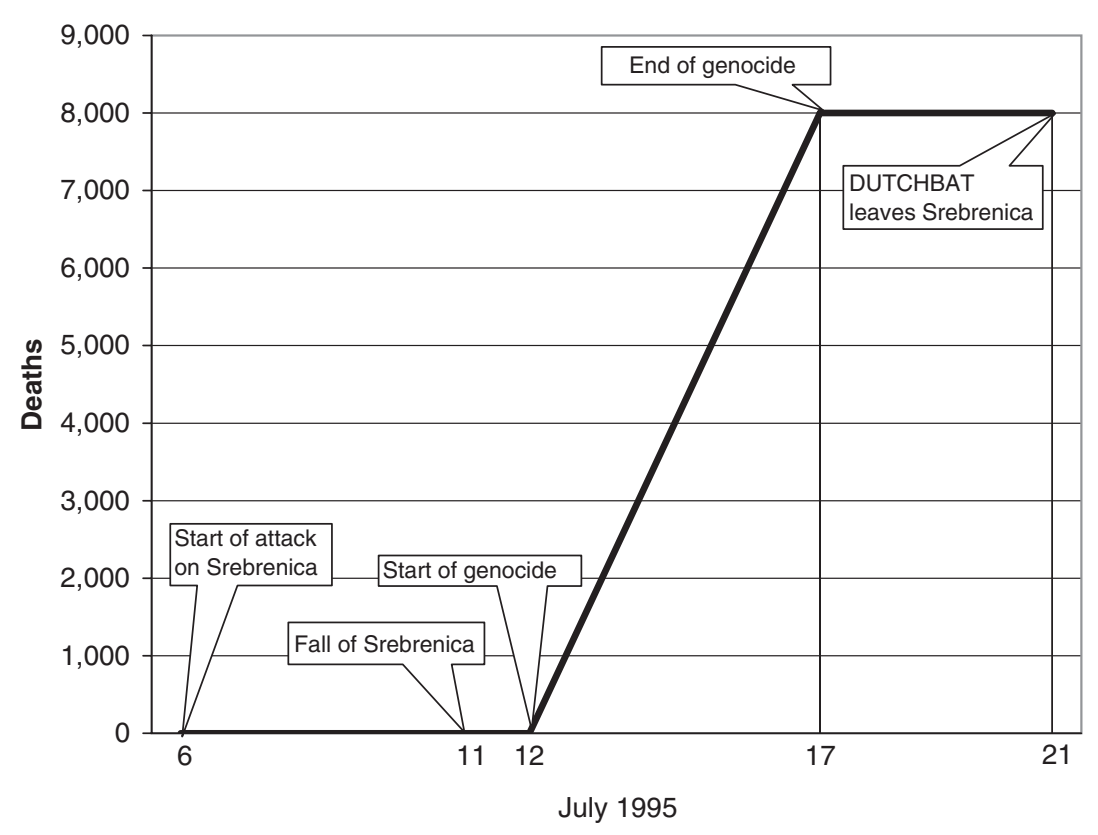

Figure 2. Deaths in Srebrenica

is why the state of Serbia-Montenegro, for instance, was condemned by the ICJ, as noted earlier. The legal duty to act to try to prevent genocide has now been established.

(3) More than a year before the attack on Srebrenica, Tuzla, another safe area in Bosnia, was attacked by the Bosnian Serbs. The Danish and other Scandinavian troops stationed there successfully defended the enclave with force, protecting the Bosnian Muslims in Tuzla. In the fifteen-month period between these two acts of aggression, no lessons were drawn with respect to the defense of Srebrenica. ${ }^{23}$

Although the period between the fall of Srebrenica and the beginning of the genocide was very short (see Figure 2), these three factors can be considered clear warnings on which action in the Srebrenica area could have been based.

\section{Instruments}

The Scandinavian peacekeeping troops in Tuzla (NORDBATT) had at their disposal powerful military weapons, including tanks, the availability of which they negotiated before agreeing to participate in UN peacekeeping in the area. The Dutch did not have such instruments at their disposal, and the troops of the "air mobile brigade" they sent had relatively little combat experience. From a legal standpoint, their ability to use force was no different from that of the Nordic troops: both were under the mandate of the larger UNPROFOR mission, which was based on UN Security Council Resolutions 819 and 824, and both were governed by the same rules of engagement, in which conditions for the use of force were precisely spelled out. These rules granted some discretion to the force commander to act according to his assessment of the situation, and this made a tremendous difference, as was evident after the killing of the 8,000 Bosnian Muslim men at Srebrenica. 
The Dutch did not consider the strength needed, both in manpower and in weaponry, before accepting the peacekeeping mission. The decision on weaponry was taken at the national level: light armaments were chosen (a) because limited time was available for training, (b) in accordance with the current UN peacekeeping principles, and (c) to demonstrate that the weapons could be used for only self-defense, and thus avoid provoking the Serbs. However, both the UN secretary-general, Boutros BoutrosGhali, and the UNPROFOR commander, Lt.-Gen. Francis Briquemont, favored more heavy weaponry and had communicated this to the Dutch government. The Canadian peacekeepers who preceded the Dutch unit in Srebrenica informed them of the harsh conditions and the impossibility of disarming the Muslim troops in this so-called safe area. In hindsight, the difference between a weak peacekeeping force, on the one hand, and a stronger defense force to protect the safe haven and the population, on the other hand, is evident; the light weaponry of the Dutch unit was suited to the first objective, but not to the second. ${ }^{24}$ The strength of Dutchbat was inadequate to defend the enclave when it was confronted with such explicit aggression. Nonetheless, three factors must be considered to put this evaluation in context.

First, the Dutch troops did not attempt to defend the enclave, nor did they try to hinder the deportation of the Muslim men. They were criticized for this attitude in the UN secretary-general's inquiry report, prepared by David Harland ${ }^{25}$ Second, they put themselves in a very vulnerable position from the beginning of their mission and did not urge any strengthening of troops and equipment during the three years of their stay in Bosnia, even as the situation deteriorated enormously ${ }^{26}$ - for instance, in response to the continual obstruction of Dutchbat transportation between the enclaves of Zepa and Srebrenica. ${ }^{27}$ Third, they put almost all their trust in NATO air forces based at Villafranca, in Italy, to protect them on the ground and to deter aggressors. This strategy failed particularly when peacekeepers were held hostage-the tactic of taking UN troops hostage to deter air attacks had already been used frequently by Bosnian Serb forces. On 11 July, air support had finally been activated, but several peacekeepers were taken hostage by the Bosnian Serbs, who broadcasted an ultimatum: the peacekeepers would be killed if the air attacks did not stop. This ultimatum was quickly put through to the Dutch minister of defense, Joris Voorhoeve, who then telephoned UN Special Representative Yasushi Akashi; the UN secretarygeneral, Boutros Boutros-Ghali; Willy Claes, secretary-general of NATO; the NATO Airbase at Vicenza, from which the fighter jets had been deployed; and military commanders in Bosnia, urging that air support be stopped immediately and planned actions be cancelled. The primordial reason was the Serbian threat of shelling and of harming the Dutch peacekeepers; above all, Voorhoeve feared for their safety. Other reasons were also communicated, however, including the closeness of Dutch peacekeepers to the Serbs and the refugees in between, which would make an air attack dangerous. Finally, Voorhoeve added that an air attack was no longer useful, since the enclave had already fallen. ${ }^{28}$ The air attack was stopped. It later became clear that the decision to stop the attack was made in Sarajevo by Akashi (at 4:30 p.m. on 11 July) before Voorhoeve's telephone call to him (which was made at 4:50 p.m.). ${ }^{29}$ Although Akashi made the decision to cancel the peacekeepers' air support without influence from the Dutch government, he repeatedly stated that "the SRSG [Akashi] felt that he had no other choice but to comply with this request."30 The argument that the Serbian and Dutch military were too close to each other for NATO to begin an air attack was also made by Gen. Bernard Janvier, the UN military commander in Zagreb, and by Gen. Frank van Kappen, military advisor to the UN secretary-general in New York. 
The argument that the safe area had already been conquered by the Serbs was put forward by NATO military commanders as well. The threat of killing peacekeepers was very effective. In Rwanda, as we have seen, most peacekeeping forces were withdrawn after the killing of ten Belgian peacekeepers. In Srebrenica, military action was aborted following a threat to kill Dutch peacekeepers. The result, in both situations, was that the targeted populations became very vulnerable and were no longer protected; the génocidaires were not hindered by any third party.

\section{Decision Making}

The Dutch government had almost no involvement in the decision making (or lack of decision making) in the Security Council. This is remarkable, given that Dutch peacekeepers were on the ground in Srebrenica to protect the safe area. Only after the fall of Srebrenica was Voorhoeve, the Dutch minister of defense, informed by his intelligence service that two or three of his NATO allies and permanent members of the Security Council (the United Kingdom, the United States, and France) had spoken in May about a possible attack on Srebrenica, and that they decided not to take any action to prevent such an attack ${ }^{31}$ nor did they inform the government of the Netherlands at that time. ${ }^{32}$ By the time the attack took place, the Security Council had been incorrectly informed at least twice. ${ }^{33}$ The false information provided gave the impression that what was taking place was not outright aggression but minor fighting in the field, to which no forceful response was required. This misinformation was distributed to the members of the Security Council by the UN Secretariat. Four days after the attack, Security Council members were again briefed with false information. Just after the attacks began, urgent requests for air support received by the UN were not sent to the Security Council; moreover, "the day before Srebrenica fell we [the UN Secretariat] reported that the Serbs were not attacking when they were. We reported that the Bosniacs had fired on an UNPROPOR blocking position when it was the Serbs.."34

The inadequate information passed on to the members of the Security Council was thus of pivotal importance in both cases: the situation in Rwanda was perceived as a civil war, and the attack on Srebrenica was not perceived as outright aggression. Irrespective of other factors or of the reasons for these misperceptions, the genocides that followed in both cases were not seen as presenting an imminent danger by the decision makers in New York. After the fall of Srebrenica and during the days of the subsequent genocide, all bystanders became collaborators with the perpetrators, resulting in the first genocide in Europe since the Holocaust.

\section{Darfur}

\section{Warning}

While the onset of the conflict in Darfur is disputed, it is assumed here that the emergence of the Darfur Liberation Front (DLF) in claiming responsibility for an attack on a military garrison in Golo, in the Jebel Marrah district in February 2003, marks the de facto beginning of the rebellion. Soon thereafter, the Sudanese government retaliated with aerial bombardments of towns in Darfur. ${ }^{35}$ Although some authors rightfully refer to the root causes of the conflict as relating to historical ethnic, economic, and geographical factors, ${ }^{36}$ this attack was on a new scale that had not been publicly predicted before. 
The direct cause of this conflict stems from the inferior position of the people of Darfur, who expected to get a better position, comparable with the greater autonomy accorded to South Sudan. ${ }^{37}$ This is one of the reasons that the Darfur conflict has always been linked in many ways to the North-South conflict in Sudan. The main lines of reasoning to prioritize the North-South over the Darfur conflict were the following:

(1) Only after the North-South conflict is resolved can the issue of Darfur be resolved. ${ }^{38}$

(2) North-South solutions are delayed to postpone involvement in Darfur. ${ }^{39}$

(3) North-South agreement must never be endangered by Darfur. ${ }^{40}$

(4) North-South as priority should be stabilized with military peacekeeping only to that area and not to Darfur. The UN Mission in Sudan (UNMIS) was restricted to the North-South conflict and could not be deployed in the Darfur region as well. ${ }^{41}$

Gérard Prunier concluded from all these arguments that cooperating in the NorthSouth negotiations allow the Sudanese government to commit genocide in Darfur without risk of foreign interference. ${ }^{42}$

The reservations listed above on action against the rising conflict in Darfur should be taken into account. Information about what was going on in Darfur was available and made public in 2003 by NGOs (Amnesty International was the first, followed by the International Crisis Group ${ }^{43}$ ), states (e.g., The Netherlands ${ }^{44}$ ), and international organizations (e.g., Jan Egeland and Mukesh Kapila of the UN Office for the Coordination of Humanitarian Affairs, OCHA ${ }^{45}$ ). In 2004 the United States and the European Parliament followed with very strong statements. ${ }^{46}$ At that time the conflict was still rather limited. Thus, in 2003 warnings had been sounded, but the Security Council did not discuss the issue. ${ }^{47}$ It is remarkable that between the beginning of 2003 and September 2004 no decision was made by the Security Council to prevent an escalation of the gross human-rights violations beyond the 10,000 killings that had already taken place in a year's time. In later stages-since September 2004-the scale of killings increased significantly, as acknowledged by policy makers at the time. ${ }^{48}$ At this point it was no longer possible to speak about preventive actions; instead, the debate that took place centered on limiting or resolving the conflict and was, therefore, not about the magnitude, scope, seriousness, or frequency of the conflict and the gross human-rights violations it involved but, rather, about the choice to be made as to what action could be taken. It was in July 2004 that the UN Security Council adopted a very weak resolution to disarm the Janjaweed-but without any sanctions against the Sudanese government if it should fail to do so. ${ }^{49}$ By 9 September 2004, the American government, through secretary of state Colin Powell, had labeled the situation in Darfur a genocide, based on a field-mission report that made clear that the deliberate killings were focused on one ethnic group, sparing civilians from another ethnic group in the nearby village. ${ }^{50}$ Figure 3 makes strikingly evident that after the adoption of this weak resolution in July 2004, atrocities began to take place on a much larger scale. The increase in the number of killings was very large-yet no one responded with forceful actions, although the deterioration of the situation in the second half of 2004 was reported and discussed at the United Nations. We will now examine the instruments used by the UN in the period between 2003 and 2008. 


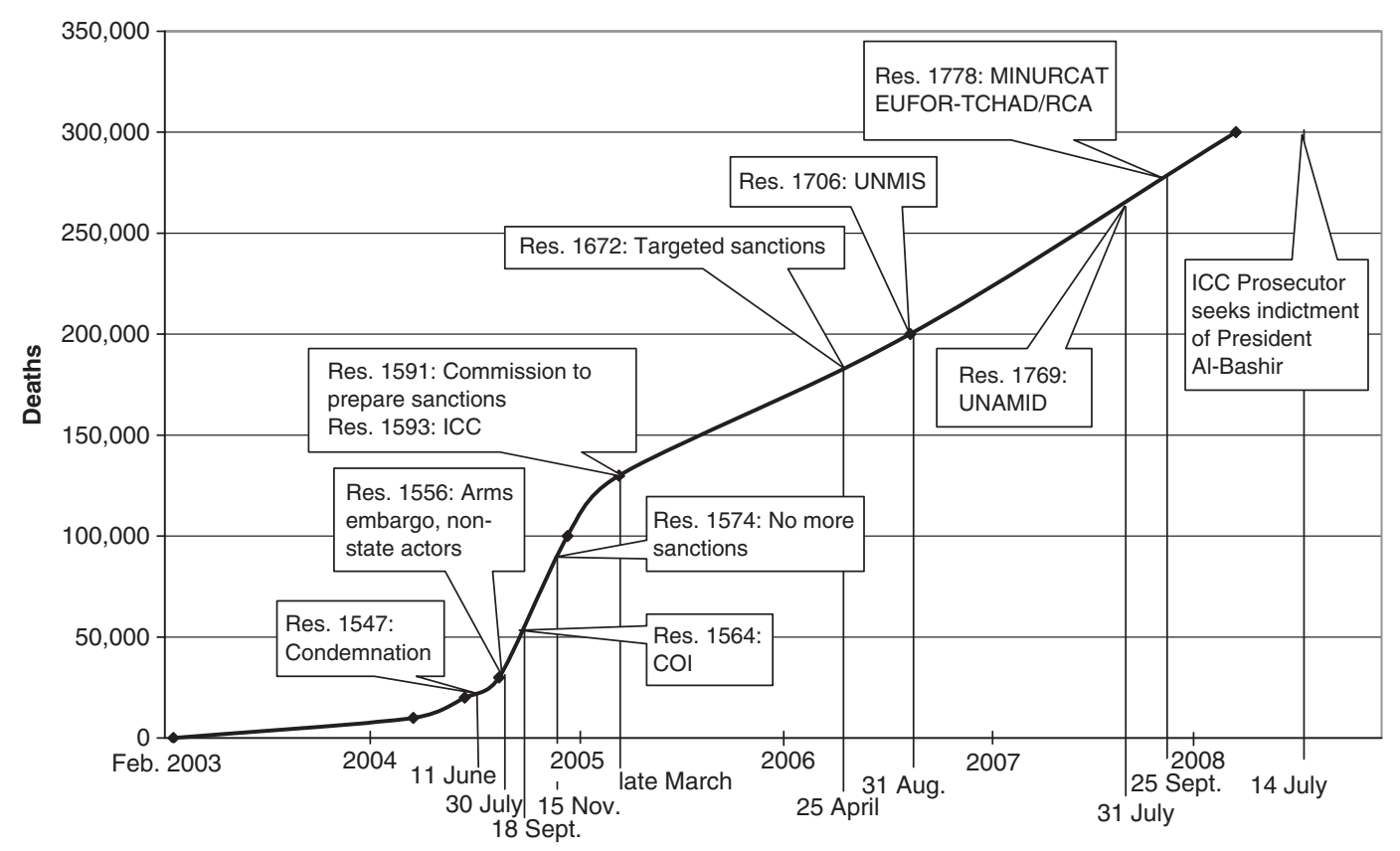

Figure 3. Deaths in Darfur (for data on casualties see note 6)

\section{Instruments}

The first UN official to raise the question of Darfur was the UN humanitarian coordinator for Sudan, Mukesh Kapila, in November 2003. ${ }^{51}$ Kapila labeled the situation the most alarming humanitarian emergency in the world. The UN coordinator of OCHA, Jan Egeland, was also very concerned about the large-scale ethnic cleansing, and he urged immediate action. ${ }^{52}$ The secretary-general took the opportunity of the memorial ceremonies for the tenth anniversary of the Rwandan Genocide, in April 2004, to address the situation in Darfur. ${ }^{53}$ Ceasefires failed to hold, and the situation worsened; concern was expressed in a presidential statement by the Security Council on 26 May. The first more concrete action was the recognition of the crisis by the Security Council in June 2004, when Resolution 1547, addressing the North-South Sudan peace process, mentioned "bring[ing] an immediate halt to the fighting in Darfur." $"$ At the end of July, in Resolution 1556, the Security Council imposed an arms embargo on the militias in Sudan and threatened the government of Sudan with sanctions if it had not disarmed the Janjaweed within thirty days. This resolution had some impact: within a week, a twelve-point Darfur Action Plan was agreed on between the Sudanese government and the UN special representative for Sudan, Jan Pronk. ${ }^{55}$ The threat of sanctions was then removed; Jan Pronk reported to the Security Council two months later that the situation had again worsened and large-scale militia violence had resumed. ${ }^{56}$ The Security Council reacted with two more severe resolutions. First, in September 2004, when the United States had already determined that the Sudanese were committing genocide and the European Parliament had labeled the situation "tantamount to genocide," " a resolution was adopted to establish a commission of inquiry to investigate whether or not the term genocide was applicable in this case. ${ }^{58}$ The Security Council's concern about the situation in Sudan, and particularly the North-South peace process, was great, and, 
at the initiative of the United States, the next meeting on Darfur took place in Nairobi. The Comprehensive Peace Agreement of November 2004 addressed the North-South Sudanese conflict but did not address Darfur. The overwhelming opinion was that once the large-scale, long-lasting North-South conflict was resolved, a resolution for Darfur would automatically follow, particularly because leaders of the South were now involved in the government. ${ }^{59}$

Because all the focus was on success in the North-South peace process, the threat of sanctions on Darfur was not repeated in November 2004. The hope for a positive development was not realized, however: on the contrary, because the Sudanese government now had more freedom to act in Darfur and no longer feared international pressure, warfare in Darfur increased, leading to a sharp rise in the number of killings, from 100,000 in November 2005 to 200.000 in August 2006 (see Figure 3). The Sudanese government successfully played on the fears of other states that an intervention in Darfur would jeopardize the peaceful end of the North-South Sudanese civil war-Africa's longest war-which had resulted in 2 million deaths. The UN was increasingly reluctant to undertake any active involvement with respect to Darfur, leaving that role to the African Union. The AU had already pledged a peacekeeping mission of more than 3,300 personnel, but in October 2004 possessed only 597 soldiers (deployed as a protection force for observers), ${ }^{60}$ while experts assessed that a relatively small number of well-equipped troops-approximately 5,000, which could have been made available quickly in July 2004, according a British chief of general staff ${ }^{61}$-could have protected the camps in Darfur, provided humanitarian assistance, and set up a no-fly zone (as had been proposed by the US Senate and European Parliament in the spring of $2004^{62}$ ). The Sudanese government succeeded over the following years in obstructing any interference, with the support of both China and Russia in the Security Council, which, over the long term, has resulted in a declining willingness to act. This is a remarkable outcome, because the domestic pressure on Western democracies to act in Darfur was very strong-particularly across the United States.

Over the past three years, a stalemate has been more or less maintained. On 31 March 2005, after the publication of the report of the UN Commission of Inquiry, the Security Council adopted a resolution "to bring all those responsible to justice," and the case of Darfur was referred to the International Criminal Court (ICC) in order to prosecute the perpetrators of the atrocities; on 29 March 2005 a resolution was adopted to establish a commission to prepare on targeted sanctions on specific persons and travel bans on the members of the government of Sudan. ${ }^{63}$ This is not a firm position, however, because no instruments have been applied. Figure 3 shows that from mid-2005 on, the killings failed to slow from the increased pace reached by October 2004.

In 2006 the pressure was high to achieve some result, which led, for instance, to a Security Council ministerial meeting in May and a visit by all Security Council members in June to investigate the situation in Sudan/Darfur and Chad. The results, however, were meager. The proposed expansion of the UNMIS peacekeeping force in South Sudan to Darfur was adopted in August 2006 but never implemented. ${ }^{64}$ Since then two decisions have been taken with respect to the peacekeeping force. On 25 September 2007, a peacekeeping mission (MINURCAT-EUFOR TCHAD/RCA) was established in Chad and the Central African Republic to protect refugees from Darfur. By this time a combined peacekeeping force about 31,000 UN and AU troops (UNAMID) had been proposed and adopted on 31 July 2007. ${ }^{65}$ However, the implementation of this resolution was made conditional on Sudan's consent to the 
equipment of the troops and the selection of the troop-contributing countries, which Sudan has given only on a case-by-case basis. ${ }^{66}$ Moreover, in the mean time the UN has weakened this instrument relative to the August 2006 mandate (Resolution 1706): the peacekeepers now lacks both the authorization to disarm the militias and a mandate to use all necessary means to protect civilians. It is very sad to observe that the assignment in the mandate of 2006 - "to seize or collect arms or related material"was not repeated in the mandate of 2007. The UN Secretariat's prohibition on searches for weapons in Rwanda in 1994 has been seen as critical to the failure to prevent that genocide. Politics do not seem to have changed, and policy makers on Darfur have not learned from the lessons of Rwanda and Srebrenica.

\section{Decision Making}

In contrast to the cases of Rwanda and Srebrenica, as we have seen, the Security Council has been fully aware of the situation in Darfur. The Security Council has been informed every month by many parties, including UN Office of the High Commissioner for Human Rights in Geneva, on the current situation in Darfur. Public opinion has been outspoken, with much pressure on Western governments from their domestic constituencies to change the situation in Darfur and to act. Nonetheless, the Sudanese government has been able to resist this pressure, through a series of small accommodations and minor diplomatic moves, without ever really changing the situation on the ground. Sudan is one of the more powerful states in the world, and can afford not to give in, because of support from African and Arab states and from two permanent members of the Security Council (China and Russia). The greatest pressure was brought to bear in 2005 and 2006, but this pressure has also waned; the Security Council has brought only two indictments to the ICC, neither of which the Sudanese government is taking seriously. In 2008, the Security Council again urged Sudan to "cooperate fully with the Court" on the two indictments. ${ }^{67}$ In fact, one of those charged-former interior minister Ahmed Haroun-was appointed minister of humanitarian affairs and advisor on human rights after his indictment. In July 2008, the ICC prosecutor also sought the indictment of Sudanese president Omar al-Bashir; an arrest warrant was issued by the ICC on 4 March 2009.

The United Nations has also failed to declare a no-fly zone, and UNAMID forces are still not fully deployed in the Darfur region to protect the internally displaced persons in the camps; so the atrocities are continuing. The UN has again failed an important test of the responsibility to protect.

\section{Conclusions}

This comparative genocide study has led us to the following conclusions on early warnings, available instruments, decision-making processes, and outcomes.

The early warnings on Rwanda were very clear, reliable, outspoken, and linked with a policy recommendation to the responsible decision makers. With respect to Srebrenica, the warnings were not clear and outspoken at the moment of decision; reconstruction of warnings is possible only in hindsight. The information available to some permanent members of the Security Council and to the UN Secretariat was not made public and did not lead to any preventive strategy. The warnings on Darfur were clear and reliable, and were made public at an early stage; in addition, the atrocities in Darfur were spread over a relatively long period, which made the development and implementation of a preventive policy possible. The data on Darfur, unlike the data on Rwanda and Srebrenica, were available to and discussed in the Security Council. 
The instruments to prevent genocide in Rwanda and in Srebrenica were available. UN peacekeeping forces were deployed and could have been strengthened. In Rwanda, moreover, the peacekeepers could have been empowered to stop the genocide by combining their troops with the evacuation forces. In Srebrenica, lessons could have been drawn from the successful and effective defense of another safe haven by Scandinavian peacekeepers. In Darfur, the instruments were not available because of lack of consent from the Sudanese government and the Security Council's inability to enforce troop deployment: at least two permanent members of the Security Council rejected proposals for mandatory decisions. Moreover, the Sudanese North-South peace process was prioritized over the Darfur conflict, which has led to a postponement of action in Darfur in order not to jeopardize the North-South accord.

Decision making in the Security Council was hampered in the case of Rwanda by the actions of those civil servants at the UN Secretariat who had primary responsibility for supplying and withholding information on the conflict, and who perceived the situation as a peacemaking processing involving the installation of a transitional government and not as an emerging genocide. The UN Secretariatand, in particular, the DPKO-therefore favored a neutral rather than a confrontational position. A shift in perception from facilitating the implementation of a peace accord toward preventing an emerging genocide was needed, but no such shift took place.

In the case of Srebrenica, only after the fall of the "safe area" did the Security Council begin enforcement measures against the Bosnian Serbs, which ultimately resulted in the Dayton Accords. The available NATO air support was not used at the moment of the attack and was deployed only to a limited extent four days later; the Dutch peacekeeping force did not resist or deter the Bosnian Serb aggression. Moreover, over the five days of the genocide no decision was made to step in to contain the situation.

Beginning in 2004, the topic of Darfur was continually on the agenda of the Security Council; public opinion in the United States and Europe put pressure on political leaders to act on the issue, and Security Council members were briefed monthly by the UN Secretariats in New York and Geneva. No longer was a separation between peace and security, on the one hand, and protection of human rights, on the other hand, maintained. The situation was taken very seriously. For instance, at one point all members of the Security Council gathered in the region for a meeting. Nonetheless, because of the strong political position of the government of Sudan in the world and among some members of the Security Council, no action was taken against Sudan. Until now, all measures with respect to Darfur have been undertaken with the consent of the Sudanese government.

In retrospect, we can say that in all three cases genocide was not prevented because, at the appropriate moment, effective measures were not undertaken. For instance, the situation would have been different if the UN had acted against the extremist militia in Rwanda in February and March 1994, or against the Bosnian Serbs in Srebrenica in May and June 1995, by strengthening peacekeeping forces in manpower and in mandate. The situation in Darfur is different, because no UN peacekeepers were deployed; however, there was sufficient time to react in Darfur, as the first full-scale killings did not take place until a year of after the first warnings were received. Yet, between February 2003 and mid-2005, no real or effective measures were undertaken to prevent the gross violations of human rights that were taking place in the region. 


\section{Notes}

1. Alison Des Forges, Leave None to Tell the Story: Genocide in Rwanda (New York: Human Rights Watch, 1999), 15-16, estimates a total of 500,000 fatalities; a letter from the UN Secretary-General to the Security Council, 16 December 19991 (UN Doc. S/1999/1257), cites approximately 800,000 fatalities; Organization of African Unity, Rwanda: The Preventable Genocide [OAU Report], gives a range of 500,000 to 800,000. See also Catrien Bijleveld, "Missing Pieces: Some Thoughts on the Methodology of the Empirical Study of International Crimes and Other Gross Human Rights Violations," in Supranational Criminology: Towards a Criminology of International Crimes, ed. Alette Smeulders and Roelof Havemans, 77-97 (Antwerp: Intersentia, 2008), on the difficulty of correctly estimating the number of casualties.

2. Fred Grünfeld and Anke Huijboom, The Failure to Prevent Genocide in Rwanda: The Role of Bystanders (Leiden: Martinus Nijhoff, 2007).

3. Fred Grünfeld, "The Role of Bystanders in Rwanda and Srebrenica: Lessons Learned," in Supranational Criminology: Towards a Criminology of International Crimes, 457-86 (Antwerp: Intersentia, 2008).

4. Bacre Waly Ndiaye, Question of the Violation of Human Rights and Fundamental Freedoms in Any Part of the World, with Particular Reference to Colonial and other Dependent Countries and Territories: Extrajudicial, Summary or Arbitrary Executions, Addendum: Report by Mr B.W. Ndiaye, Special Rapporteur, on His Mission to Rwanda from 8 to 17 April 1993, UN Doc. E/CN.4/1994/7/Add.1 (11 August 1993), §79 [Ndiaye Report].

5. Basic sources include Ingavar Carlsson, Han Sung-Joo, and Rufus M. Kupolati, United Nations Report of the Independent Inquiry into the actions of the United Nations during the 1994 Genocide in Rwanda, UN Doc. S/1999/1257 (15 December 1999) [Carlsson Report]; OAU Report; Assemblée Nationale de France, Rapport d'information, "Mission d'information sur le Rwanda," No. 1271 (December 1998); Sénat de Belgique, Rapport de la Commission d'enquête parlementaire concernant les événements au Rwanda (6 December 1997) [Belgian Senate Report]; Des Forges, Leave None to Tell the Story. Scholarly works include, on the role of the UN, Michael Barnett, Eyewitness to a Genocide: The United Nations and Rwanda (London: Cornell University Press, 2002); Linda Melvern, A People Betrayed: The Role of the West in Rwanda's Genocide (London: Zed Books, 2000); on the role of the United States, Samantha Power, "A Problem from Hell": America and the Age of Genocide (1959-1994) (New York: HarperPerennial, 2003); on the role of France, Olivier Lanotte, La France au Rwanda (1990-1994): entre abstention impossible et engagement ambivalent (Brussels: Pie-Peter Lang, 2007).

6. Case concerning Application of the Convention on the Prevention and Punishment of the Crime of Genocide (Bosnia and Herzegovina v. Yugoslavia), Judgment, 26 February 2007, para. 430.

7. Note that the figures given here include not only direct killings but also casualties from sickness and harm resulting from the miserable circumstances of flight and refugee camps. Unlike the figures mentioned for Rwanda and Srebrenica, casualty numbers from Darfur take in a much broader range of victims by including those indirectly killed by the war. The relevant figures for an analysis of decision making are those publicly stated by the decision makers: February 2003: Start of conflict; 31 April 2004: 10,000 deaths (EU Parliamentary Resolution P5-TA (2004) 0225); 13 July 2007: 20,000 deaths (UN estimate); 9 September 2004: 30,000 (US Department of State, Documenting Atrocities in Darfur, State Publication No. 11182 (21 September 2004)); 11 January 2005: 100,000 deaths (UN envoy Pronk to the Security Council, UN Doc. S/PV.5109); 31 March 2005: 130,000 deaths (statement by the United States to the UN Security Council, UN Doc. S/PV.5158); 18 September 2006: 200,000 deaths (statement by the United Kingdom to the Security Council, UN Doc. S/PV.5528); 23 April 2008: 300,000 deaths (John Holmes, UN head of humanitarian affairs, BBC News). 
8. Gérard Prunier, Darfur: An Ambiguous Genocide, rev. ed. (London: C. Hurst, 2007); Alex de Waal, Famine That Kills: Darfur, Sudan (Oxford: Oxford University Press, 2005); M.W. Daly, Darfur's Sorrow: A History of Destruction and Genocide (Cambridge: Cambridge University Press, 2007).

9. Colin L. Powell, "The Crisis in Darfur" (written remarks before the Senate Foreign Relations Committee, 9 September 2004), http://2001-2009.state.gov/secretary/former/ powell/remarks/36042.htm (accessed 12 June 2009).

10. Report of the International Commission of Inquiry on Darfur to the United Nations Secretary-General, Pursuant to Security Council Resolution 1546 of 18 September 2004, UN Doc. S/2005/60 (25 January 2005), http://www.un.org/News/dh/sudan/com_inq_ darfur.pdf (accessed 12 June 2009).

11. The term was first introduced by John Prendergast and Anthony Lake, "Stopping Sudan's Slow-Motion Genocide," Boston Globe, 20 May 2004.

12. See Amnesty International, "Rwanda: Persecution of Tutsi Minority and Repression of Government Critics 1990-1992" (AI document AFR 47/002/92, 1 May 1992).

13. See Ndiaye Report.

14. E.g., Johan Swinnen, the Belgian ambassador to Rwanda (see Belgian Senate Report, 493-95); CIA reports in January 1993 (Power, A Problem from Hell, 338) and January 1994 (Des Forges, Leave None to Tell the Story, 159 n. 77; Melvern, A People Betrayed, 91).

15. Their request was supported by the Belgian prime minister, Willy Claes: see Belgian Senate Report, 342, 392; Carlsson Report, 13. See further Grünfeld and Huijboom, Failure to Prevent Genocide in Rwanda, chapter 11.

16. See particularly Barnett, Eyewitness to a Genocide, chapter 4 (for the bureaucratic-politics view of the UN Department of Peacekeeping Operations); Linda Melvern, "The Security Council in the Face of Genocide," Journal of International Criminal Justice 3 (2005): 847-60.

17. More than 1,700 elite troops from the United States, France, Italy, and Belgium were either flown in or placed on standby in neighboring countries immediately after the plane crash, when the evacuation of their nationals was ordered. If these 1,700 well-armed, well-trained elite troops had been added to the 2,500 UNAMIR soldiers on the ground, the combined force would have totaled 4,200: exactly the number of soldiers requested by all Rwandan parties to the Arusha Peace Accords in 1993, and the number considered realistic by the military personnel who prepared the peacekeeping mission. Grünfeld and Huijboom, Failure to Prevent Genocide in Rwanda, chapter 14.

18. See especially Barnett, Eyewitness to a Genocide, 111.

19. J.C.H. Blom et al., Srebrenica, een 'veilig' gebied. Reconstructie, achtergronden, gevolgen en analyse van de val van een Safe Area (Amsterdam: Boom, 2002).

20. Television interview with Joris Voorhoeve, former Dutch minister of defense, ten years after Srebrenica (9 July 2005), http://nos.nl/nosjournaal/artikelen/2005/7/9/ 090705_voorhoeve_srebrenica.html (accessed 19 June 2009).

21. C. Wiebes, NIOD_Intelligence and the War in Bosnia 1992-1995: The Role of the Intelligence and Security Service (New Brunswick, NJ: Transaction Publishers, 2002).

22. Andreas Zumach, US Intelligence Knew Serbs Were Planning an Assault on Srebrenica (Basic Report No. 47, British American Security Information Council, 16 October 1995); Andreas Zumach, New Evidence Further Implicates France in Fall of Srebrenica (Basic Report No. 56, British American Security Information Council, 11 February 1997).

23. See Grünfeld, "The Role of Bystanders," 467-70.

24. Blom et al., Srebrenica, 1123-29; Netherlands Parliamentary Inquiry Report on Srebrenica (Tweede Kamer, file no. 28 506, nos.2-3, pp. 71-74; no. 5, p. 482.

25. Report of the Secretary-General pursuant to General Assembly Resolution 53/35, UN Doc. A/54/549 (15 November 1999) [Srebrenica Report].

26. Blom et al., Srebrenica, 1911-12.

27. Srebrenica Report, $§ 165$.

28. Joris (J.C.C.) Voorhoeve, Letter to the editor, NRC-Handelsblad, 2 May 1998. 
29. Blom et al., Srebrenica, 2240-41, 2300-2308.

30. Srebrenica Report, §306.

31. ARGOS Interview with Joris Voorhoeve, Part 1 (VPRO's De Ochtenden-Radio 1-December 22, 2006) [English transcript], http://www.domovina.net/archive/2006/ 20061222_argose.php (accessed 22 June 2009).

32. Wiebes, NIOD, 145.

33. Srebrenica Report, §282.

34. Srebrenica Report, §496.

35. Prunier, Darfur, 99.

36. De Waal, Famine That Kills; Daly, Darfur's Sorrow.

37. Alex Cobham, "Causes of Conflict in Sudan: Testing The Black Book," European Journal of Development Research 17 (2005): 462-80.

38. This line of argument was backed by the UN Secretariat-see "Interview: Kieran Prendergast," Frontline (PBS, 29 June 2007), http://www.pbs.org/wgbh/pages/frontline/ darfur/interviews/prendergast.html (accessed 22 June 2009); statement by UN SecretaryGeneral Kofi Annan, UN Security Council Meeting No. 5080 (18 November 2004)—but also by some Western countries. James Traub, The Best Intentions: Kofi Annan and the UN in the Era of American World Power (New York: Farrar, Straus \& Giroux, 2006), 217.

39. "Interview: Mukesh Kapila," Frontline (PBS, 11 June 2007), http://www.pbs.org/wgbh/ pages/frontline/darfur/interviews/kapila.html (accessed 22 June 2009).

40. House of Commons International Development Committee (UK), Darfur, Sudan: The Responsibility to Protect (5th Report of Session 2004-05, 30 March 2005), vol. 1, 36-37.

41. This line of reasoning was voiced in a Security Council meeting in Nairobi, Kenya, UN Doc. S/PV.5080 (18 November 2004). The extension of UNMIS to cover Darfur was addressed in Resolution 1706, UN Doc. S/RES/1706 (31 August 2006).

42. Prunier, Darfur, 116.

43. Amnesty International, Crisis in Darfur: Urgent Need for International Commission of Inquiry and Monitoring (AI document AFR/54/026/2003, 28 April 2003); International Crisis Group, "Sudan's Other Wars,” Africa Briefing 14 (25 June 2003).

44. Ministerie van Buitenlandse Zaken, Ambtsbericht Soedan Juli 2003 [Ministry of Foreign Affairs, Note on Sudan (July 2003)].

45. "Humanitarian Situation Worsens in Greater Darfur Region of Western Sudan," UN OCHA Doc. AFR/721-IHA/805 (7 October 2003).

46. On 24 June 2004, several US diplomats expressed their concern for the situation in Darfur: Eric Markusen and Samuel Totten, eds., Genocide in Darfur: Investigating the Atrocities in the Sudan (New York: Routledge, 2006), xxiv; Colin Powell, then US secretary of state, described the situation as "genocide": Colin L. Powell, "The Crisis in Darfur" (written remarks before the Senate Foreign Relations Committee, 9 September 2004), http://2001-2009.state.gov/secretary/former/powell/remarks/36042.htm (accessed 12 June 2009); US Department of State, Documenting Atrocities in Darfur, State Publication 11182 (Washington, DC: US Department of State, 2004). The European Parliament issued a first resolution concerning Darfur, P5_TA(2004)0225, on 31 March 2003; a further resolution on Sudan, EU Doc. P6_TA(2004)0012, on 16 September 2004, calls the situation "tantamount to genocide."

47. Mukesh Kapila and Jan Egeland both sent several reports and internal memos to the UN Secretariat from October 2003 onward.

48. See statement by the United States to the UN Security Council, UN Doc. S/PV.5158, in which the US notes 30,000 casualties in September 2004 and 130,000 in April 2005.

49. UN Security Council Resolution 1556, UN Doc. S/RES/1556 (30 July 2004).

50. See Powell, "The Crisis in Darfur"; US Department of State, Documenting Atrocities in Darfur.

51. This message was first made public by OCHA on 5 December 2003. Several months later, Kapila compared the Darfur situation with Rwanda in a BBC news radio interview:

"Mass Rape Atrocity in West Sudan," BBC News, 19 March 2004. 
52. The term "ethnic cleansing" was first used in Jan Egeland, "Sudan: Ethnic Cleansing in Darfur," UN Doc. RCHC/SUD/Note39 (22 March 2004).

53. “'Risk of Genocide Remains Frighteningly Real,' Secretary-General Tells Human Rights Commission as He Launches Action Plan to Prevent Genocide (Press Release), UN Doc. SG/SM/9245 AFR/893 HR/CN/1077, http://www.un.org/News/Press/docs/2004/ sgsm9245.doc.htm (accessed 22 June 2009).

54. UN Doc. S/RES/1547 (11 June 2004).

55. Report of the Secretary-General pursuant to paragraphs 6 and 13 to 16 of Security Council Resolution 1556 (2004), UN Doc. S/2004/703 (30 August 2004), §7-11.

56. Minutes of the 5071st Meeting of the UN Security Council, UN Doc. S/PV.5071 (4 November 2004)

57. EU Doc. P6_TA(2004)0012.

58. UN Security Council Resolution 1565, UN Doc. S/RES/1564 (18 September 2004).

59. Statement by the Secretary-General and SPLM/A leader Garang, UN Doc. S/PV.5080 (18 November 2004); Statement by China, Russia, Germany, UK, France, and the USA, UN Doc. S/PV.5082 (19 November 2004); Report of the Representative of the Secretary-General on Internally Displaced Persons, Francis M. Deng. Mission to the Sudan-The Darfur Crisis, UN Doc. E/CN.4/2005/8 (27 September 2004), §33. See further the sources cited in note 37 above. For scholarly works see Paul D. Williams and Alex J. Bellamy, "The Responsibility to Protect and the Crisis in Darfur," Security Dialogue 36 (2005): 27-47; Alex De Waal, "Darfur and the Failure of the Responsibility to Protect," International Affairs 86 (2007): 1039-54; Eric A. Heinze, "The Rhetoric of Genocide in U.S. Foreign Policy: Rwanda and Darfur Compared," Political Science Quarterly 122 (2007): 359-83.

60. "The African Union Deploys More Troops in Darfur as Part of Its Efforts to Strengthen AMIS" (Press release no. 098/2004, 28 October 2004), http://www.africa-union.org/ News_Events/Press_Releases/98\%2004\%20press\%20release\%20darfur\%2027\%2010\% 2004.pdf (accessed 23 June 2009).

61. Williams and Bellamy, "The Responsibility to Protect," 34.

62. US Senate, "To promote peace and accountability in Sudan, and for other purposes," 109th Congress, 1st Sess., S. 1462 (21 July 2005), 14 row 16; EU Doc. P5_TA(2004)0225.

63. UN Doc. S/RES/1593 (31 March 2005); S/RES/1591 (29 March 2005).

64. UN Doc. S/RES/1706 (31 August 2006).

65. UN Doc. S/RES/1778 (25 September 2007); UN Doc. S/RES/1769 (31 July 2007).

66. Minutes of the 5784th Meeting of the UN Security Council, UN Doc. S/PV.5784 (27 November 2007).

67. Statement by the President of the Security Council, UN Doc. S/PRST/2008/21 (16 June 2008). 